Article

\title{
Characterization of $\mathrm{Pt}_{-\mathrm{TiO}_{2}}$ film used in three formaldehyde photocatalytic degradation systems: $\mathrm{UV}_{254 \mathrm{~nm}}, \mathrm{O}_{3}+\mathrm{UV}_{254 \mathrm{~nm}}$ and $\mathrm{UV}_{254+185} \mathrm{~nm}$ via X-ray photoelectron spectroscopy
}

\author{
Pingfeng Fua, Pengyi Zhang b,* \\ a School of Civil and Environment Engineering, University of Science and Technology Beijing, Beijing 100083, China \\ b State Key Joint Laboratory of Environment Simulation and Pollution Control, School of Environment, Tsinghua University, Beijing 100084, China
}

A R T I C L E I N F O

Article history:

Received 28 September 2013

Accepted 23 October 2013

Published 20 February 2014

Keywords:

Platinum nanoparticle

Vacuum ultraviolet

Photocatalysis

Ozone decomposition

Catalyst deactivation

\begin{abstract}
A B S T R A C T
Photocatalytic degradation of gaseous formaldehyde for $35 \mathrm{~h}$ was performed using $\mathrm{Pt}^{-\mathrm{TiO}_{2}}$ film in the following irradiation systems: $\mathrm{UV}_{254 \mathrm{~nm}}, \mathrm{O}_{3}+\mathrm{UV}_{254 \mathrm{~nm}}$, and $\mathrm{UV}_{254+185 \mathrm{~nm}}$. Concurrent improvements in formaldehyde degradation and $\mathrm{O}_{3}$ removal were achieved by modifying $\mathrm{TiO}_{2}$ with Pt nanoparticles, resulting in a 3.1-3.4-fold $\mathrm{O}_{3}$ elimination increase. X-ray photoelectron spectroscopy (XPS) of the $\mathrm{Pt}-\mathrm{TiO}_{2}$ film was carried out to assess the electronic states of the Pt nanoparticles and accumulated organic species. The deconvoluted C $1 s$ and $01 s$ XPS spectra revealed that the content of carbonyl and carboxyl groups on $\mathrm{Pt}^{-\mathrm{TiO}_{2}}$ and degree of catalyst deactivation in the systems studied decreased in the following order: $\mathrm{UV}_{254 \mathrm{~nm}}>\mathrm{O}_{3}+\mathrm{UV}_{254 \mathrm{~nm}}>\mathrm{UV}_{254+185 \mathrm{~nm}}$. Metallic $\mathrm{Pt}^{0}$ was oxidized to a mixture of $\mathrm{PtO}_{a d s}$ and $\mathrm{Pt}^{4+}$ species under $\mathrm{O}_{3}+\mathrm{UV}_{254 \mathrm{~nm}}$ and $\mathrm{UV}_{254+185} \mathrm{~nm}$ irradiation owing to the presence of $\mathrm{O}_{3}$ and hydroxyl radicals, but remained stable under $\mathrm{UV}_{254 \mathrm{~nm}}$ irradiation. Pt species at higher oxidation states can act as electron trapping centers, and improve the photocatalytic activity of $\mathrm{Pt}^{-\mathrm{TiO}_{2}}$ and provide reactive sites for $\mathrm{O}_{3}$ decomposition under UV irradiation, resulting in a faster $\mathrm{O}_{3}$ removal rate than that displayed by $\mathrm{TiO}_{2}$. The XPS studies provided valuable information to elucidate the beneficial role of Pt species and the reduction of catalyst deactivation under $\mathrm{UV}_{254+185 \mathrm{~nm}}$ irradiation.
\end{abstract}

(C) 2014, Dalian Institute of Chemical Physics, Chinese Academy of Sciences. Published by Elsevier B.V. All rights reserved.

\section{Introduction}

$\mathrm{TiO}_{2}$-based heterogeneous photocatalytic oxidation (PCO) is cost-effective and can operate at room temperature and atmospheric pressure. Hence, it has been widely investigated to decompose gaseous pollutants such as volatile organic compounds (VOCs) [1-4]. Formaldehyde (HCHO) is a major indoor pollutant, and efficient removal of it in air has attracted great attention [5-7]. However, some key problems, such as catalyst deactivation $[8,9]$ and inhibition effect of other molecules (e.g., $\mathrm{H}_{2} \mathrm{O}$, NO) $[10,11]$, hinder the practical application of PCO. Various approaches have been employed to overcome these drawbacks such as combination of PCO with microwave [12], ozone $[13,14]$, and adsorption $[15,16]$.

Vacuum ultraviolet (VUV, $\lambda<200 \mathrm{~nm}$ ) with high-energy photons can dissociate oxygen and water molecules into reactive oxygen species (e.g., $\mathrm{O}\left({ }^{1} \mathrm{D}\right), \mathrm{O}\left({ }^{3} \mathrm{P}\right)$, and $\left.\mathrm{O}_{3}\right)$ and hydroxyl radicals $(\bullet \mathrm{OH})$, which can readily react with various VOCs in

\footnotetext{
* Corresponding author. Tel: +86-10-62796840-601; Fax: +86-10-627977602; E-mail: zpy@tsinghua.edu.cn

This work was supported by the National Natural Science Foundation of China (21221004), the National High Technology Research and Development Program of China (863 Program, 2012AA062701), and the Special Fund of State Key Joint Laboratory of Environment Simulation and Pollution Control (12K04ESPCT).
} 
gas phase [17-19]. The photocatalytic efficiency in removing indoor VOCs remarkably increases under $U_{254+185} \mathrm{~nm}$ irradiation (UV with $\lambda_{\max }=254 \mathrm{~nm}$ and minor VUV $\lambda=185 \mathrm{~nm}$ ) compared with that achieved under common $U_{254} \mathrm{~nm}$ or $U_{365} \mathrm{~nm}$ irradiation [17-20]. Furthermore, catalyst deactivation is reduced by effective decomposition of nonvolatile intermediates on the catalyst surface $[18,19]$. Therefore, photocatalysis under $\mathrm{UV}_{254+185 \mathrm{~nm}}$ irradiation is a facile and effective PCO technique for indoor air purification. However, hazardous contaminant $\mathrm{O}_{3}$ is also generated via dissociation of $\mathrm{O}_{2}$ with VUV $[17,18]$. In general, removal of $\mathrm{O}_{3}$ byproduct, generated during photoca-

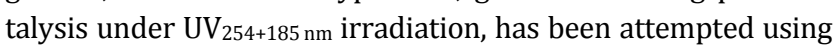
two routes: photocatalysis followed by ozone destruction catalysis [18,20], and in situ catalytic destruction using modified photocatalysts, e.g., $\mathrm{TiO}_{2}$ modified with noble metals [21]. We previously found that $\mathrm{Pd}$-modified $\mathrm{TiO}_{2}$ films could simultaneously increase the formaldehyde degradation and $\mathrm{O}_{3}$ elimination under $U^{254+185} \mathrm{~nm}$ irradiation [21]. Additionally, the redox processes of $\mathrm{Pd}$ species under $\mathrm{UV}_{254+185 \mathrm{~nm}}$ irradiation were critical for the simultaneous decomposition of formaldehyde and $\mathrm{O}_{3}$. The electronic states of the noble metal are likely to remarkably differ when noble metal-modified photocatalysts are applied in $\mathrm{UV}_{254 \mathrm{~nm}}$ and $\mathrm{UV}_{254+185 \mathrm{~nm}}$ irradiation photocatalytic systems owing to the presence of VUV-photochemically generated reactive species. Therefore, it is necessary to identify the electronic states of metal species when noble metal-modified photocatalysts are applied in the UV $254+185 \mathrm{~nm}$ irradiation photocatalytic system.

Lowering of catalyst deactivation was reported for the photocatalytic decomposition of formaldehyde [21], toluene $[17,20]$, and benzene [18] under $\mathrm{UV}_{254+185 \mathrm{~nm}}$ irradiation. Gaseous reaction intermediates were measured to compare the photocatalytic degradation performance under $U_{254} \mathrm{~nm}$ and $\mathrm{UV}_{254+185 \mathrm{~nm}}$ irradiation [18,22], thus to indirectly elucidate the

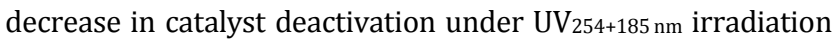
compared to $\mathrm{UV}_{254 \mathrm{~nm}}$ irradiation. It is well known that accumulation of reaction intermediates on the catalyst surface is a key factor resulting in catalyst deactivation. Hence, quantification of accumulated intermediates could provide direct evidence for assessing degree of catalyst deactivation. However, little information on surface properties of photocatalysts has been reported to directly explain the low degree of catalyst deactivation under $\mathrm{UV}_{254+185 \mathrm{~nm}}$ irradiation.

In this work, we investigated the performance of Pt-modified $\mathrm{TiO}_{2}$ films $\left(\mathrm{Pt}-\mathrm{TiO}_{2}\right)$ to photocatalytically remove formaldehyde and $\mathrm{O}_{3}$ under $\mathrm{UV}_{254+185 \mathrm{~nm}}$ irradiation. To illustrate the mechanism of reduction of catalyst deactivation and elucidate the role of deposited Pt nanoparticles on decomposing $\mathrm{O}_{3}$, a comparative X-ray photoelectron spectroscopy (XPS) study was conducted to assess the accumulation of organic species on the catalyst surface and changes of the Pt valence states in the $\mathrm{Pt}_{-} \mathrm{TiO}_{2}$ films under three irradiation systems: $\mathrm{UV}_{254} \mathrm{~nm}$,

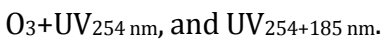

\section{Experimental}

\subsection{Fabrication and characterization of $\mathrm{Pt}-\mathrm{TiO}_{2}$ films}

$\mathrm{TiO}_{2}$ films coated on a $\mathrm{Ti}$ wire net ( 40 mesh) $\left(\mathrm{TiO}_{2} / \mathrm{Ti}\right)$ were fabricated via a sol-gel dip coating method [23]. Pt nanoparticles (NPs) were deposited on the $\mathrm{TiO}_{2} / \mathrm{Ti}$ wire net using a low-temperature electrostatic self-assembly method, as described elsewhere [21,24]. $\mathrm{H}_{2} \mathrm{PtCl}_{6}$ solution $(100 \mathrm{~mL}, 0.3$ $\mathrm{mmol} / \mathrm{L}$ ) containing polyvinyl alcohol (PVA, $300 \mathrm{mg}$ ) was cooled in an ice water bath, to which a fresh $\mathrm{NaBH}_{4}$ solution (4 $\mathrm{mL}, 0.07 \mathrm{~mol} / \mathrm{L}$ ) was rapidly added under sonication to obtain a reduced $\mathrm{Pt}$ colloidal solution. A piece of $\mathrm{TiO}_{2} / \mathrm{Ti}$ wire net $(L \times W=80 \mathrm{~mm} \times 80 \mathrm{~mm})$ was then immersed into the fresh $\mathrm{Pt}$ colloidal solution. The negatively charged Pt NPs were spontaneously adsorbed onto the positively charged $\mathrm{TiO}_{2}$ surface via electrostatic interactions at $\mathrm{pH} \approx 4$. The self-assembly time was $30 \mathrm{~min}$. The $\mathrm{TiO}_{2} / \mathrm{Ti}$ wire net was removed from the solution and washed with boiling water to remove adsorbed chloride ions. The dried $\mathrm{TiO}_{2} / \mathrm{Ti}$ wire net was then annealed in air at $300{ }^{\circ} \mathrm{C}$ for $1.5 \mathrm{~h}$ to fabricate the $\mathrm{Pt}^{-\mathrm{TiO}_{2}}$ film.

The morphology of the samples was observed using an ultra-high-resolution field-emission scanning electron microscope (FESEM, S-5500, Hitachi). X-ray diffraction (XRD) analysis was carried out on a Rigaku D/max-RB using $\mathrm{Cu} K \alpha$ radiation $(\lambda=0.15418 \mathrm{~nm})$, operating at $40 \mathrm{kV}$ and $100 \mathrm{~mA}$. The surface properties of the $\mathrm{Pt}^{-\mathrm{TiO}_{2}}$ films were investigated by XPS (PHI-5300, ESCA) at a pass energy of $50 \mathrm{eV}$, using $\mathrm{Al} K_{\alpha}$ as an exciting X-ray source. The base pressure in the measurement chamber was $4.53 \times 10^{-7} \mathrm{~Pa}$. The spectra were calibrated with respect to the $\mathrm{C} 1 \mathrm{~s}$ line of graphitic carbon at $284.8 \mathrm{eV}$. Prior to individual elemental scans, a survey scan was conducted to detect all of the present elements. XPSPEAK software (version 4.1) with a Gaussian-Lorentzian mixed function and Shirley background subtraction was employed to deconvolute the XPS spectra. The peak positions were reproducible as well as the fixed Lorentz/Gaussian ratio of 1:4 and FWHM of the peaks.

\subsection{Photocatalytic decomposition studies}

The experimental setup is the same as that used in our previous work [21]. All UV lamps were purchased from Guangdong Cnlight Company. Two UV254+185 nm lamps $(2 \times 3 \mathrm{~W})$, i.e., ozone-producing low-pressure mercury lamps with $\lambda_{\max }$ at 254 $\mathrm{nm}$ and a minor emission (ca. 5\%) at $\lambda=185 \mathrm{~nm}$, were placed in the center of the flow-through reactor with an effective volume of $0.628 \mathrm{~L}$. Two pieces of $\mathrm{Pt}_{-} \mathrm{TiO}_{2} / \mathrm{Ti}$ wire nets were fixed at both sides of the lamp, respectively. The flow rate was fixed at $1.8 \mathrm{~L} / \mathrm{min}$. The inlet concentration of $\mathrm{HCHO}$ was set at ca. $0.52 \mathrm{mg} / \mathrm{m}^{3}$. After the inlet and outlet HCHO concentrations reached equilibrium, the $U_{254+185} \mathrm{~nm}$ lamps were turned on. All photocatalytic experiments ran for $35 \mathrm{~h}$. The UV lamps were then turned off to allow the system to equilibrate again. For the $\mathrm{O}_{3}$-enhanced $\mathrm{UV}_{254} \mathrm{~nm}\left(\mathrm{O}_{3}+\mathrm{UV}_{254 \mathrm{~nm}}\right)$ photocatalysis setup, two low-pressure mercury lamps $\left(\lambda_{\max }=254 \mathrm{~nm}, 2 \times 3 \mathrm{~W}\right)$, which do not produce $\mathrm{O}_{3}$, were used. A mixture of $\mathrm{HCHO}$ and $\mathrm{O}_{3}$ gases was introduced into the reactor. The concentration of added $\mathrm{O}_{3}$ (ca. $22.5 \mathrm{mg} / \mathrm{m}^{3}$ ) is comparable with that generated by the two $\mathrm{UV}_{254+185 \mathrm{~nm}}$ lamps. The subsequent steps were the same as those employed in the $\mathrm{UV}_{254+185 \mathrm{~nm}}$ irradiation photocatalytic system. Photocatalysis under $\mathrm{UV}_{254} \mathrm{~nm}$ irradiation was carried 
out in the same manner as photocatalysis under $\mathrm{O}_{3}+\mathrm{UV}_{254 \mathrm{~nm}}$ irradiation except that no $\mathrm{O}_{3}$ was added.

The $\mathrm{O}_{3}$ concentration was monitored with an online $\mathrm{O}_{3}$ analyzer (Model 49i, Thermo Electron). The formaldehyde concentration was analyzed by the MBTH method (GB/T18204.28, China). A KI-coated annular denuder was used to remove $\mathrm{O}_{3}$ for possible interference with formaldehyde analysis.

The $\mathrm{HCHO}$ reaction rate $\left(R_{\mathrm{HCHO}}, \mathrm{mg} /\left(\mathrm{m}^{3} \cdot \mathrm{min}\right)\right)$ and $\mathrm{O}_{3}$ decomposition rate $\left(R_{03}, \mathrm{mg} /\left(\mathrm{m}^{3} \cdot \mathrm{min}\right)\right)$ were calculated as follows:

$$
\begin{gathered}
R_{\mathrm{HCHO}}=\left[Q \times\left([\mathrm{HCHO}]_{\text {initial }}-[\mathrm{HCHO}]_{\text {steady }}\right)\right] / V \\
R_{03}=\left[Q \times\left(\left[\mathrm{O}_{3}\right]_{\text {vuv }}-\left[\mathrm{O}_{3}\right]_{\text {steady }}\right)\right] / V
\end{gathered}
$$

where $[\mathrm{HCHO}]_{\text {initial }}$ is the equilibrium concentration of $\mathrm{HCHO}$ before irradiation; [HCHO $]_{\text {steady }}$ is the steady-state outlet concentration of $\mathrm{HCHO}$ following the 35 -h photocatalytic reaction; $\left[\mathrm{O}_{3}\right]$ vuv is the outlet concentration of the VUV-generated $\mathrm{O}_{3}$ (in the absence of photocatalysts) or the added $\mathrm{O}_{3}\left(22.5 \mathrm{mg} / \mathrm{m}^{3}\right)$; $\left[\mathrm{O}_{3}\right]_{\text {steady }}$ is the steady-state concentration of $\mathrm{O}_{3}$ in the $\mathrm{O}_{3}+$ $\mathrm{UV}_{254 \mathrm{~nm}}$ and $\mathrm{UV}_{254+185 \mathrm{~nm}}$ irradiation photocatalytic systems; $Q$ $\left(\mathrm{m}^{3} / \mathrm{min}\right)$ is the flow rate of $\mathrm{HCHO}$ gas; and $V\left(\mathrm{~m}^{3}\right)$ is the effective volume of the reactor.

\section{Results and discussion}

\subsection{Characterization of Pt- $\mathrm{TiO}_{2}$ films}

An ultra-high-resolution FESEM image of the $\mathrm{Pt}^{-\mathrm{TiO}_{2}}$ film is shown in Fig. 1. Pt NPs (white dots) were uniformly dispersed on the $\mathrm{TiO}_{2}$ surface. The average size of the Pt NPs was $1.9 \mathrm{~nm}$, indicating the presence of a large amount of surface unsaturated atoms in Pt NPs. The surface density of the Pt NPs was $1.43 \times 10^{12} \mathrm{NPs} / \mathrm{cm}^{2}$, which was almost one order of magnitude higher than that of deposited Pd NPs in our previous work [21]. As shown in Fig. 1 inset, approximately 4-8 Pt NPs were deposited onto each $\mathrm{TiO}_{2}$ particle. The uniform dispersion of ultrafine Pt NPs is beneficial for increasing the amount of reactive sites and metal- $\mathrm{TiO}_{2}$ contact area.

XRD patterns (Fig. 2) suggest that the as-synthesized $\mathrm{TiO}_{2}$ film has a well-organized crystal structure, comprising $62.5 \%$ anatase and $37.5 \%$ rutile. Following the self-assembly process,

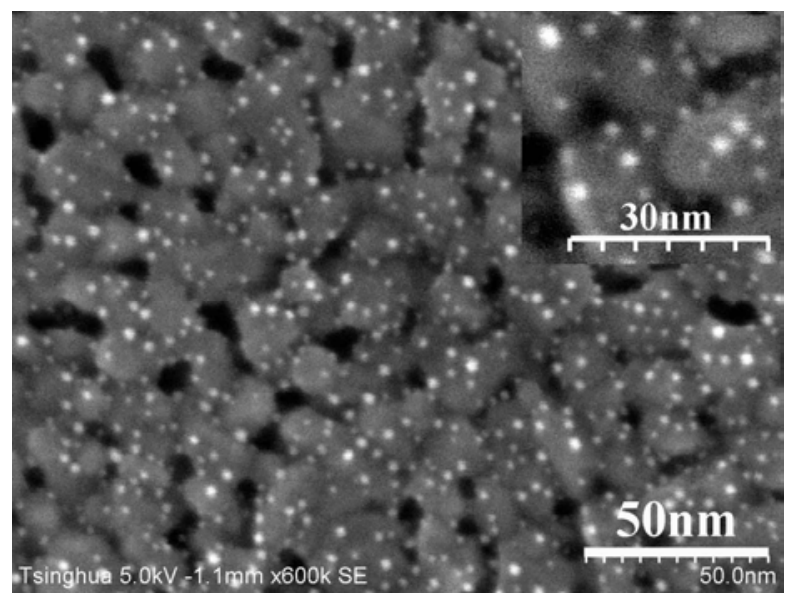

Fig. 1. Ultra high-resolution FESEM image of $\mathrm{TiO}_{2}$ film modified with $\mathrm{Pt}$ nanoparticles.

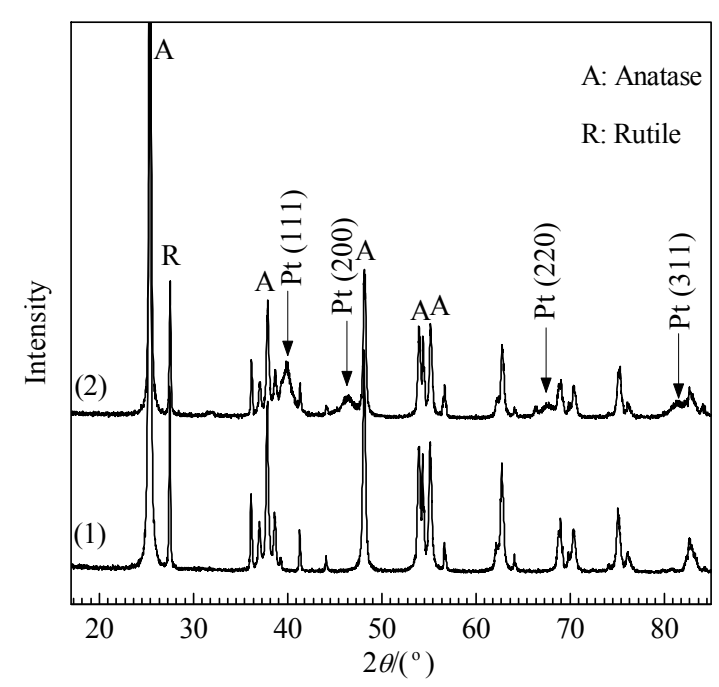

Fig. 2. XRD patterns of as-prepared $\mathrm{TiO}_{2}(1)$ and $\mathrm{Pt}-\mathrm{TiO}_{2}$ film (2) (in the absence of the Ti wire net support).

the resulting crystalline structure of $\mathrm{TiO}_{2}$ showed no notable changes. The presence of Pt NPs in the $\mathrm{Pt}-\mathrm{TiO}_{2}$ film is indicated by the diffraction peaks at $2 \theta=39.9^{\circ}, 46.4^{\circ}, 67.5^{\circ}$, and $81.3^{\circ}$ (Fig. 2) that can be attributed to the (111), (200), (220), and (311) reflections of metallic Pt (JCPDS 4-0802), respectively. The broad diffraction peaks strongly indicate the nanocrystalline nature of the deposited Pt NPs. The XRD result reveals that the metallic form of the deposited Pt NPs was maintained following annealing in air at $300^{\circ} \mathrm{C}$.

\subsection{Photocatalytic $\mathrm{HCHO}$ degradation and $\mathrm{O}_{3}$ elimination}

The performance of $\mathrm{HCHO}$ degradation and $\mathrm{O}_{3}$ elimination using pure $\mathrm{TiO}_{2}$ and $\mathrm{Pt}_{-} \mathrm{TiO}_{2}$ photocatalysts was assessed under $\mathrm{UV}_{254} \mathrm{~nm}, \mathrm{O}_{3}+\mathrm{UV}_{254} \mathrm{~nm}$, and $\mathrm{UV}_{254+185} \mathrm{~nm}$ irradiation. Figure 3 presents the $\mathrm{HCHO}$ reaction rate as a function of irradiation time over $\mathrm{TiO}_{2}$ and $\mathrm{Pt}-\mathrm{TiO}_{2}$ photocatalysts under the three irradiation processes. The degradation rate of HCHO decreased in the order of $U_{254+185} \mathrm{~nm}>\mathrm{O}_{3}+\mathrm{UV}_{254 \mathrm{~nm}}>\mathrm{UV}_{254 \mathrm{~nm}}$ for both photocatalysts studied. As HCHO can be easily degraded in gas phase via photochemical processes under 185-nm VUV irradiation, the HCHO degradation rate under $\mathrm{UV}_{254+185 \mathrm{~nm}}$ irradiation was the highest among the three processes. Deactivation of the pure $\mathrm{TiO}_{2}$ and $\mathrm{Pt}-\mathrm{TiO}_{2}$ did not take place under $\mathrm{UV}_{254+185} \mathrm{~nm}$ irradiation, as indicated by the absence of a decreased HCHO reaction rate during the 35 -h photocatalytic process. However, reduced $\mathrm{HCHO}$ reaction rates were noted in both $\mathrm{O}_{3}+\mathrm{UV}_{254} \mathrm{~nm}$ and $\mathrm{UV}_{254 \mathrm{~nm}}$ irradiation systems at reaction time above $25 \mathrm{~h}$, resulting in catalyst deactivation. Nevertheless, a lower degree of catalyst deactivation could be observed in the $\mathrm{O}_{3}+\mathrm{UV}_{254 \mathrm{~nm}}$ irradiation system relative to the $\mathrm{UV}_{254 \mathrm{~nm}}$ irradiation system owing to the addition of $\mathrm{O}_{3}$.

In the $\mathrm{UV}_{254 \mathrm{~nm}}$ photocatalytic system, the steady-state $\mathrm{HCHO}$ reaction rate over $\mathrm{Pt}-\mathrm{TiO}_{2}$ was ca. 1.3-fold higher than that over pure $\mathrm{TiO}_{2}$, thereby indicating the positive effect of Pt NPs in improving the photocatalytic activity of $\mathrm{Pt}_{-} \mathrm{TiO}_{2}$. In addition, the $\mathrm{HCHO}$ reaction rate decreased much faster in the case of pure 

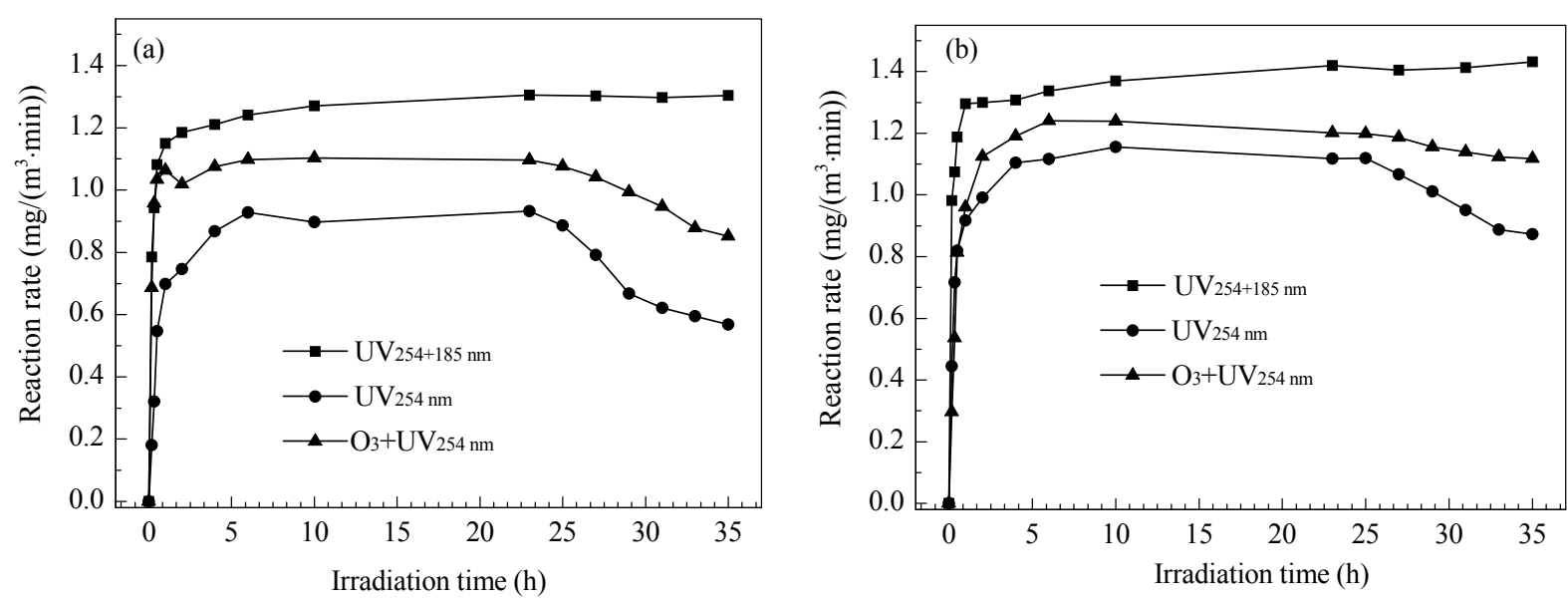

Fig. 3. Degradation rate of $\mathrm{HCHO}$ as a function of irradiation time under $\mathrm{UV}_{254 \mathrm{~nm}}, \mathrm{O}_{3}+\mathrm{UV}_{254} \mathrm{~nm}$, and $\mathrm{UV}_{254+185 \mathrm{~nm}}$ irradiation over pure $\mathrm{TiO}_{2}(\mathrm{a})$ and $\mathrm{Pt}^{-\mathrm{TiO}_{2}}$ films (b).

$\mathrm{TiO}_{2}$, showing that modification with Pt NPs was beneficial to reducing catalyst deactivation. Furthermore, as shown in Fig. 3, under $\mathrm{O}_{3}+\mathrm{UV}_{254 \mathrm{~nm}}$ and $\mathrm{UV}_{254+185 \mathrm{~nm}}$ irradiation, the $\mathrm{HCHO}$ reaction rate obtained over the $\mathrm{Pt}-\mathrm{TiO}_{2}$ films was higher than that over pure $\mathrm{TiO}_{2}$. These results indicate that deposition of Pt NPs on $\mathrm{TiO}_{2}$ is beneficial to increasing the photocatalytic degradation efficiency of $\mathrm{HCHO}$ in all three processes.

Figure 4 shows the $\mathrm{O}_{3}$ decomposition performance under $\mathrm{O}_{3}+\mathrm{UV}_{254 \mathrm{~nm}}$ and $\mathrm{UV}_{254+185} \mathrm{~nm}$ irradiation. Despite the very low decrease in the $\mathrm{O}_{3}$ decomposition rates observed over both pure $\mathrm{TiO}_{2}$ and $\mathrm{Pt}-\mathrm{TiO}_{2}$ films in the early stages of the process, in general, the reaction rate was relatively constant throughout the 35-h photocatalytic process, indicating that both $\mathrm{TiO}_{2}$ and $\mathrm{Pt}_{-} \mathrm{TiO}_{2}$ did not deactivate under $\mathrm{O}_{3}+\mathrm{UV}_{254} \mathrm{~nm}$ or $\mathrm{UV}_{254+185} \mathrm{~nm}$ irradiation. The $\mathrm{O}_{3}$ decomposition rate over the $\mathrm{Pt}_{-} \mathrm{TiO}_{2}$ films was much higher than that over pure $\mathrm{TiO}_{2}$, resulting in a 3.1-3.4-fold enhancement regardless of whether the $\mathrm{O}_{3}$ was introduced or generated in situ. The results clearly indicate that deposition of Pt NPs on $\mathrm{TiO}_{2}$ remarkably enhances the $\mathrm{O}_{3}$ decomposition. The $\mathrm{O}_{3}$ decomposition rate over $\mathrm{Pt}_{-} \mathrm{TiO}_{2}$ was 1.4-fold higher relative to that over previously reported

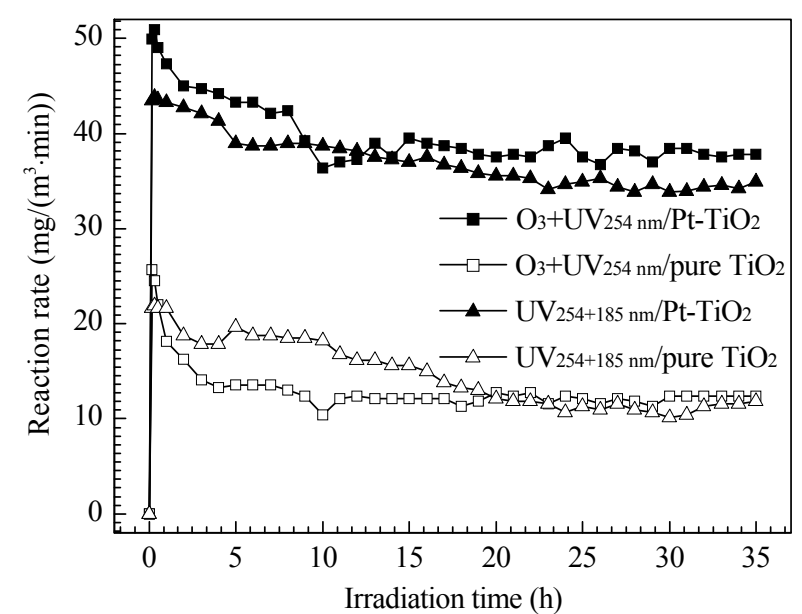

Fig. 4. Photocatalytic decomposition rate of $\mathrm{O}_{3}$ as a function of irradiation time under $\mathrm{O}_{3}+\mathrm{UV}_{254 \mathrm{~nm}}$ and $\mathrm{UV}_{254+185 \mathrm{~nm}}$ irradiation over pure $\mathrm{TiO}_{2}$ and $\mathrm{Pt}-\mathrm{TiO}_{2}$ film.
$\mathrm{Pd}-\mathrm{TiO}_{2}$ films under $\mathrm{UV}_{254+185 \mathrm{~nm}}$ irradiation [21].

\section{3. $C 1 \mathrm{~s}$ and $O 1 \mathrm{~s} X P S$ study of Pt-TiO ${ }_{2}$ films}

The chemical states of carbon (oxygen)-containing functional groups of $\mathrm{Pt}_{-} \mathrm{TiO}_{2}$ films were characterized by high-resolution XPS. XPS spectra of $\mathrm{C} 1 s$ and $01 s$ of the $\mathrm{Pt}^{-\mathrm{TiO}_{2}}$ films before and after the 35-h photocatalytic process are shown in Fig. 5, and the corresponding relative content and binding energy (BE) of the functional groups are listed in Table 1 . The $01 \mathrm{~s}$ peak at 529.8-530.2 eV can be assigned to lattice oxygen of the Ti-O bond [25]. The as-prepared $\mathrm{Pt}^{-\mathrm{TiO}_{2}}$ films displayed graphitic carbon (C $1 s$ at $284.8 \mathrm{eV}$ ), C-O of alcoholic hydroxyls (C $1 s$ at $285.9 \mathrm{eV}$ ), and surface hydroxyl groups (O $1 s$ at 532.1 $\mathrm{eV}$ ) features [26,27]. The alcoholic hydroxyl groups likely correspond to residual PVA on the $\mathrm{TiO}_{2}$ surface after the annealing treatment. For the Pt-TiO 2 films, subjected to a $35-\mathrm{h} \mathrm{UV}_{254} \mathrm{~nm}$ irradiation photocatalytic process, the broad $\mathrm{C} 1 \mathrm{~s}$ peak can be deconvoluted into three bands. The $C 1 s$ peaks at 287.1 and $288.5 \mathrm{eV}$ correspond to carbon from carbonyl groups of aldehydes (37.9\%) and carboxyl groups (10.6\%), respectively $[26,28]$. The deconvoluted $01 s$ peaks at 531.8 and $534.3 \mathrm{eV}$ are assigned to carbonyl oxygen of aldehydes (32.1\%) and oxygen atoms in carboxyl groups (12.9\%), respectively [26]. Both the $\mathrm{C} 1 s$ and $01 s$ XPS spectra indicate the presence of carbonyl and carboxyl groups on the $\mathrm{Pt}_{-} \mathrm{TiO}_{2}$ surface. Previous studies have shown that the oxidation intermediates, generated during the photocatalytic decomposition of formaldehyde, are $\mathrm{CO}$ and formic acid; the latter tends to be strongly adsorbed on the catalyst surface $[29,30]$. Therefore, the carbonyl and carboxyl groups in this case can be assigned to corresponding groups in formaldehyde and formic acid adsorbed on $\mathrm{Pt}_{-} \mathrm{TiO}_{2}$, respectively. It is clear that a large amount of formaldehyde and formic acid molecules have been accumulated on the $\mathrm{Pt}-\mathrm{TiO}_{2}$ films during the $\mathrm{UV}_{254} \mathrm{~nm}$ photocatalytic process. This result is consistent with the fast deactivation of $\mathrm{Pt}_{-} \mathrm{TiO}_{2}$ under $\mathrm{UV}_{254 \mathrm{~nm}}$ irradiation as the reaction time extends over $25 \mathrm{~h}$ (Fig. 3(b)).

Both $\mathrm{C} 1 s$ and $01 s$ peaks of the resulting $\mathrm{Pt}_{-\mathrm{TiO}}$ films, following $\mathrm{O}_{3}+\mathrm{UV}_{254 \mathrm{~nm}}$ photocatalytic process for $35 \mathrm{~h}$, were nar- 

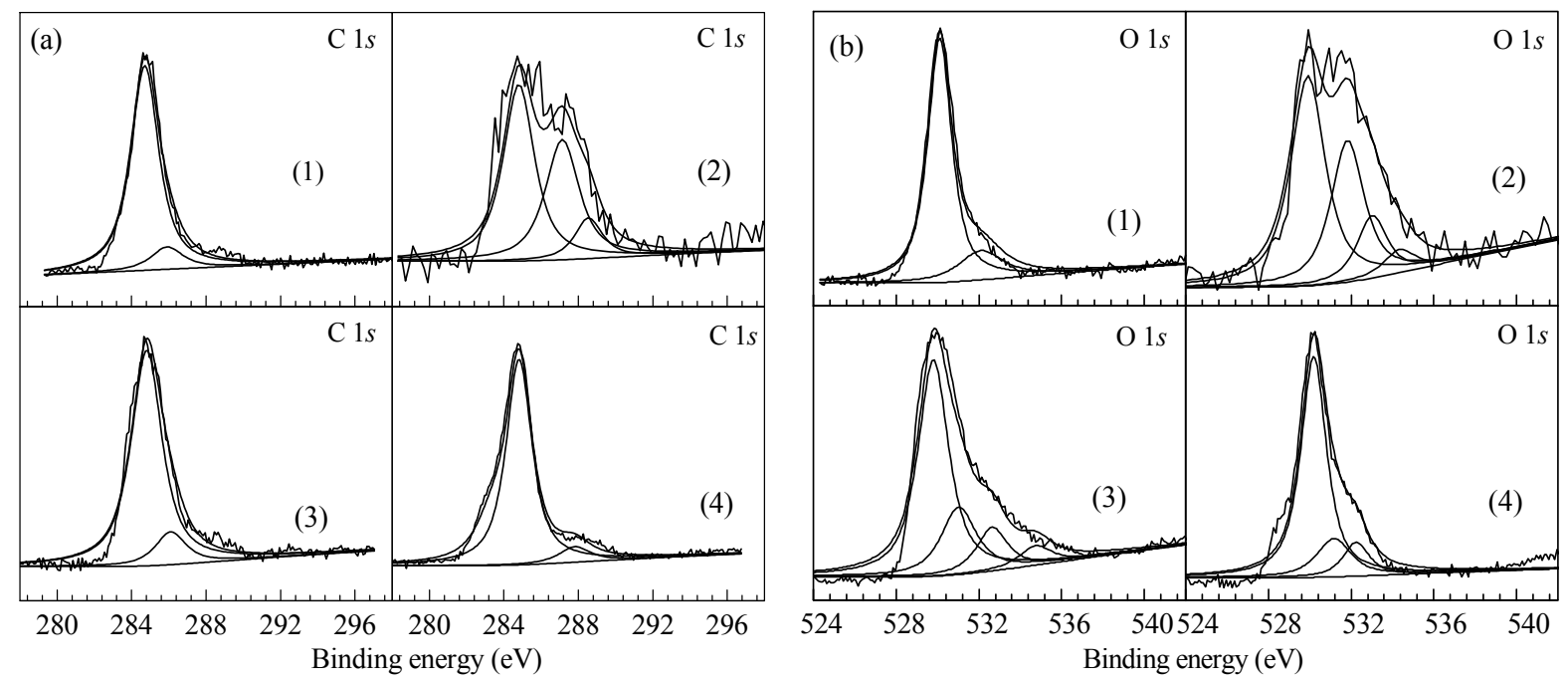

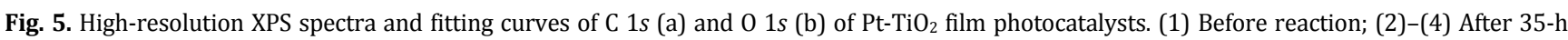
$\mathrm{UV}_{254 \mathrm{~nm}}, 35-\mathrm{h} \mathrm{O}_{3}+\mathrm{UV}_{254 \mathrm{~nm}}$, and 35-h $\mathrm{UV}_{254+185} \mathrm{~nm}$ photocatalytic processes.

Table 1

Relative content and corresponding binding energy of functional groups determined from XPS analysis for Pt- $\mathrm{TiO}_{2}$ film before and after 35 -h photocatalytic process.

\begin{tabular}{|c|c|c|c|c|c|c|c|c|}
\hline \multirow{2}{*}{$\begin{array}{l}\text { Photocatalytic } \\
\text { system }\end{array}$} & \multicolumn{4}{|c|}{ Relative content and binding energy of $01 s^{*}$} & \multicolumn{4}{|c|}{ Relative content and binding energy of C $1 s^{* *}$} \\
\hline & Peak 1 & Peak 2 & Peak 3 & Peak 4 & Peak I & Peak II & Peak III & Peak IV \\
\hline \multirow[t]{2}{*}{ Before reaction } & $81.5 \%$ & & $18.5 \%$ & & $88.9 \%$ & $11.1 \%$ & & \\
\hline & $530.1 \mathrm{eV}$ & & $532.1 \mathrm{eV}$ & & $284.7 \mathrm{eV}$ & $285.9 \mathrm{eV}$ & & \\
\hline \multirow[t]{2}{*}{$\mathrm{UV}_{254 \mathrm{~nm}}$} & $49.9 \%$ & $32.1 \%$ & $5.1 \%$ & $12.9 \%$ & $51.5 \%$ & & $37.9 \%$ & $10.6 \%$ \\
\hline & $529.9 \mathrm{eV}$ & $531.8 \mathrm{eV}$ & $532.9 \mathrm{eV}$ & $534.3 \mathrm{eV}$ & $284.8 \mathrm{eV}$ & & $287.1 \mathrm{eV}$ & $288.5 \mathrm{eV}$ \\
\hline \multirow[t]{2}{*}{$\mathrm{O}_{3}+\mathrm{UV}_{254 \mathrm{~nm}}$} & $60.5 \%$ & $21.6 \%$ & $12.2 \%$ & $5.7 \%$ & $91.7 \%$ & & $8.3 \%$ & \\
\hline & $529.8 \mathrm{eV}$ & $531.1 \mathrm{eV}$ & $532.6 \mathrm{eV}$ & $534.7 \mathrm{eV}$ & $284.8 \mathrm{eV}$ & & $287.8 \mathrm{eV}$ & \\
\hline \multirow[t]{2}{*}{$\mathrm{UV}_{254+185 \mathrm{~nm}}$} & $71.8 \%$ & $16.9 \%$ & $11.3 \%$ & & $86.8 \%$ & & $13.2 \%$ & \\
\hline & $530.2 \mathrm{eV}$ & $531.2 \mathrm{eV}$ & $532.3 \mathrm{eV}$ & & $284.8 \mathrm{eV}$ & & $286.1 \mathrm{eV}$ & \\
\hline
\end{tabular}

*Peak 1: oxygen in Ti-0 bond; Peak 2: carbonyl oxygen in aldehyde; Peak 3: oxygen in hydroxyl groups; Peak 4: oxygen in carboxyl groups.

${ }^{* *}$ Peak I: graphitic carbon; Peak II: C-O in alcoholic hydroxyls; Peak III: carbonyl groups in aldehyde; Peak IV: carboxyl groups.

rower relative to those produced following $\mathrm{UV}_{254} \mathrm{~nm}$ photocatalytic process. The $\mathrm{C} 1 \mathrm{~s}$ peak at $287.8 \mathrm{eV}$ corresponds to carbonyl groups (8.3\%) of adsorbed formaldehyde. The $01 \mathrm{~s}$ peaks at 531.1 and $534.7 \mathrm{eV}$ can be assigned to carbonyl oxygen $(21.6 \%)$ of formaldehyde and oxygen atoms (5.7\%) in carboxyl groups of formic acid, respectively $[26,28]$. The fitting results in Table 1 reveal that the accumulation of formaldehyde and formic acid on $\mathrm{Pt}_{-} \mathrm{TiO}_{2}$ decreased in the presence of $\mathrm{O}_{3}$. This may be attributed to the higher decomposition rates of formaldehyde and formic acid under $\mathrm{O}_{3}+\mathrm{UV}_{254} \mathrm{~nm}$ irradiation when compared with those under $\mathrm{UV}_{254 \mathrm{~nm}}$ irradiation. The $\mathrm{C} 1 \mathrm{~s}$ and 01s XPS findings are consistent with the observed higher HCHO reaction rate under $\mathrm{O}_{3}+\mathrm{UV}_{254 \mathrm{~nm}}$ irradiation relative to that under $U_{254} \mathrm{~nm}$ irradiation. Therefore, the lower degree of catalyst deactivation under $\mathrm{O}_{3}+\mathrm{UV}_{254} \mathrm{~nm}$ irradiation is ascribed to lower amounts of adsorbed formaldehyde and formic acid on $\mathrm{Pt}_{-} \mathrm{TiO}_{2}$. Addition of $\mathrm{O}_{3}$ has been reported to enhance the degradation of hydrophobic VOCs, and inhibits the deactivation of photocatalysts in $\mathrm{a} \mathrm{TiO}_{2} / \mathrm{UV} / \mathrm{O}_{3}$ reaction system $[31,32]$.

The $\mathrm{C} 1 s$ and $01 s$ XPS spectra of $\mathrm{Pt}^{-\mathrm{TiO}_{2}}$ film subjected to $\mathrm{UV}_{254+185 \mathrm{~nm}}$ irradiation photocatalytic process for $35 \mathrm{~h}$ are shown in Fig. 5. The deconvoluted C $1 s$ peak at $286.1 \mathrm{eV}$ can be assigned to carbonyl groups (13.2\%) of adsorbed formalde- hyde. The deconvoluted $01 s$ peak at $531.2 \mathrm{eV}$ corresponds to carbonyl oxygen $(16.9 \%)$ of formaldehyde [26,28]. It can be inferred that only a small amount of formaldehyde was accumulated on the Pt- $\mathrm{TiO}_{2}$ surface after the $35-\mathrm{h} \mathrm{UV}_{254+185} \mathrm{~nm}$ photocatalytic process. Thus, formaldehyde was effectively decomposed to final products (e.g., $\mathrm{CO}_{2}$ and $\mathrm{H}_{2} \mathrm{O}$ ) without accumulation of detectable oxidation intermediates.

The relative atomic content of $\mathrm{C}, \mathrm{O}, \mathrm{Ti}$, and Pt on the surface of $\mathrm{Pt}_{-} \mathrm{TiO}_{2}$ films before and after 35-h photocatalytic process was calculated from the corresponding peak areas of the XPS spectra (Table 2). The $\mathrm{C}$ content significantly increased from $33.21 \%$ (before photocatalytic reaction) to $39.77 \%$ and $38.89 \%$ after the $\mathrm{Pt}^{-\mathrm{TiO}_{2}}$ films were subjected to $35-\mathrm{h} \mathrm{UV}_{254} \mathrm{~nm}$ and $\mathrm{O}_{3}+\mathrm{UV}_{254} \mathrm{~nm}$ photocatalytic processes, respectively. A corresponding increase in the relative 0 content was also observed, as listed in Table 2. The significant increase in $\mathrm{C}$ and $\mathrm{O}$ contents is directly related to the accumulation of organic species on $\mathrm{Pt}-\mathrm{TiO}_{2}$ after the $35-\mathrm{h} \mathrm{UV}_{254} \mathrm{~nm}$ and $\mathrm{O}_{3}+\mathrm{UV}_{254 \mathrm{~nm}}$ photocatalytic processes. However, only a slight increase in the $\mathrm{C}$ and $\mathrm{O}$ relative atomic content was observed after the 35-h UV $254+185 \mathrm{~nm}$ photocatalytic process, which is indicative of the lowest amount of accumulated organic species among the three types of photocatalytic systems. 
Table 2

Relative atomic content of $\mathrm{C}, \mathrm{O}, \mathrm{Ti}$, and $\mathrm{Pt}$ on the surface of $\mathrm{Pt}_{-} \mathrm{TiO}_{2}$ film before and after 35-h photocatalytic process.

\begin{tabular}{lcccc}
\hline Photocatalytic & \multicolumn{4}{c}{ Relative atomic content (\%) } \\
\cline { 2 - 5 } system & $\mathrm{C}$ & $\mathrm{O}$ & $\mathrm{Ti}$ & $\mathrm{Pt}$ \\
\hline Before reaction & 33.21 & 45.88 & 16.40 & 4.51 \\
$\mathrm{UV}_{254 \mathrm{~nm}}$ & 39.77 & 47.42 & 10.77 & 2.04 \\
$\mathrm{O}_{3}+\mathrm{UV}_{254 \mathrm{~nm}}$ & 38.89 & 46.90 & 11.82 & 2.39 \\
$\mathrm{UV}_{254+185 \mathrm{~nm}}$ & 35.10 & 46.09 & 14.85 & 3.96 \\
\hline
\end{tabular}

\subsection{Pt 4 XXPS study of Pt-TiO 2 films}

XPS spectra of the Pt $4 f$ core level region of the $\mathrm{Pt}_{-} \mathrm{TiO}_{2}$ films before and after the 35-h photocatalytic process are presented in Fig. 6. Several peaks that correspond to multiple oxidation states of Pt were observed. Pt $4 f_{7 / 2}$ and $4 f_{5 / 2}$ peaks were deconvoluted into two sets of spin-orbit doublet. The BE, relative content, and peak FWHM of the different Pt species in the Pt-TiO 2 before and after the 35-h photocatalytic processes are listed in Table 3. The BE of Pt $4 f_{7 / 2}$ in the as-prepared $\mathrm{Pt}_{-} \mathrm{TiO}_{2}$ at 71.2 and $72.4 \mathrm{eV}$ can be assigned to metallic $\mathrm{Pt}^{0}(81.7 \%)$ and $\mathrm{Pt}^{2+}(18.3 \%)$, respectively [33-35]. The Pt $4 f_{7 / 2}$ peak, observed at $72.4 \mathrm{eV}$, has a lower BE than that associated with PtO species (i.e., $73.4 \mathrm{eV}$ ); thus the oxidized $\mathrm{Pt}^{2+}$ species were assigned to $\mathrm{PtO}_{\text {ads }}\left(\mathrm{Pt}^{2+}\right.$ with adsorbed oxygen) [34]. However, no oxidized Pt species appeared in the XRD analysis (Fig. 2) owing to the relatively small amount of $\mathrm{PtO}_{\text {ads }}$ in Pt NPs. Because of the large amount of unsaturated surface atoms, as featured by the Pt NPs, it is highly likely that Pt NPs partially were oxidized to $\mathrm{PtO}_{\text {ads }}$ during annealing in air at $300^{\circ} \mathrm{C}$.

Following the $35-\mathrm{hV}_{254} \mathrm{~nm}$ photocatalytic process, the Pt-TiO ${ }_{2}$ films displayed Pt $4 f_{7 / 2}$ peaks at 71.1 and $72.1 \mathrm{eV}$, which can be assigned to metallic $\mathrm{Pt}^{0}$ (79.9\%) and $\mathrm{PtO}_{\text {ads }}(20.1 \%)$, respectively [33-36]. This shows that both metallic $\mathrm{Pt}^{0}$ and $\mathrm{PtO}_{\text {ads }}$ are stable under $\mathrm{UV}_{254 \mathrm{~nm}}$ irradiation. In contrast, Pt $4 f_{7 / 2}$ peaks of the $\mathrm{Pt}-\mathrm{TiO}_{2}$ films, following a $35-\mathrm{h}_{3}+\mathrm{UV}_{254} \mathrm{~nm}$ photocatalytic process, were shifted to 72.3 and $74.2 \mathrm{eV}$, which cor-

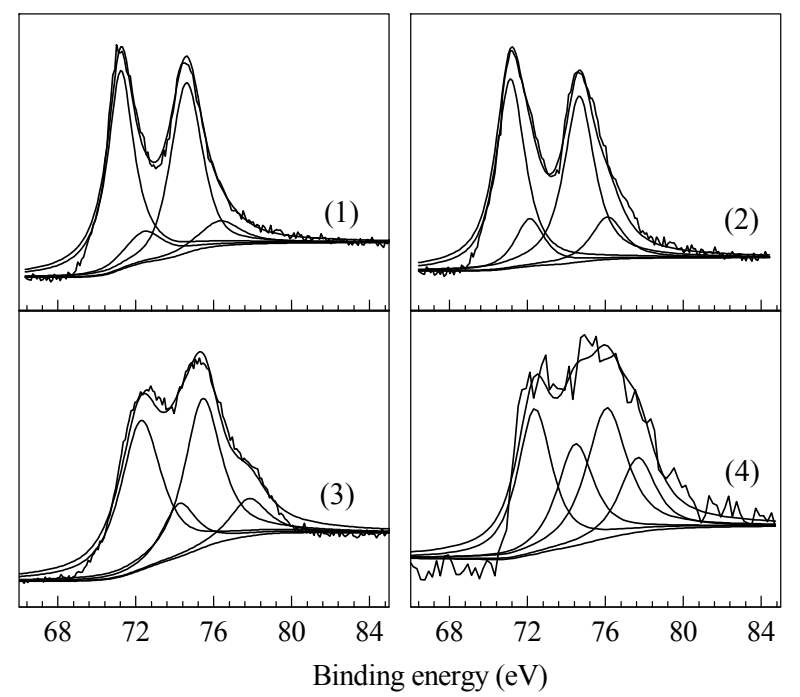

Fig. 6. High-resolution XPS spectra and fitting curves of Pt $4 f$ for $\mathrm{Pt}_{-\mathrm{TiO}}$ film photocatalysts. (1) Before reaction; (2)-(4) After 35-h $\mathrm{UV}_{254 \mathrm{~nm}}$, $35-\mathrm{h}_{3}+\mathrm{UV}_{254 \mathrm{~nm}}$, and $35-\mathrm{h} \mathrm{UV}_{254+185 \mathrm{~nm}}$ photocatalytic processes.
Table 3

Binding energy, relative content, and FWHM of deconvoluted Pt $4 f_{7 / 2}$ peaks of $\mathrm{Pt}_{-} \mathrm{TiO}_{2}$ films before and after 35 -h photocatalytic process.

\begin{tabular}{lcccc}
\hline $\begin{array}{l}\text { Photocatalytic } \\
\text { system }\end{array}$ & Pt species & $\begin{array}{c}\text { Binding } \\
\text { energy }(\mathrm{eV})\end{array}$ & $\begin{array}{c}\text { Relative } \\
\text { content }(\%)\end{array}$ & $\begin{array}{c}\text { FWHM } \\
(\mathrm{eV})\end{array}$ \\
\hline Before reaction & $\mathrm{Pt}^{0}$ & 71.2 & 81.7 & 2.14 \\
& $\mathrm{Pt}^{2+}\left(\mathrm{PtO}_{\mathrm{ads}}\right)$ & 72.4 & 18.3 & 2.49 \\
$\mathrm{UV}_{254 \mathrm{~nm}}$ & $\mathrm{Pt}^{0}$ & 71.1 & 79.9 & 2.27 \\
& $\mathrm{Pt}^{2+}\left(\mathrm{PtO}_{\mathrm{ads}}\right)$ & 72.1 & 20.1 & 2.77 \\
$\mathrm{O}_{3}+\mathrm{UV}_{254 \mathrm{~nm}}$ & $\mathrm{Pt}^{2+}\left(\mathrm{PtO}_{\mathrm{ads}}\right)$ & 72.3 & 76.9 & 2.11 \\
& $\mathrm{Pt}^{4+}$ & 74.2 & 23.1 & 2.34 \\
$\mathrm{UV}_{254+185 \mathrm{~nm}}$ & $\mathrm{Pt}^{2+}\left(\mathrm{PtO}_{\mathrm{ads}}\right)$ & 72.4 & 57.4 & 2.13 \\
& $\mathrm{Pt}^{4+}$ & 74.5 & 42.6 & 2.54 \\
\hline
\end{tabular}

respond to $\mathrm{PtO}_{\text {ads }}(76.9 \%)$ and $\mathrm{Pt}^{4+}$ species (23.1\%), respectively [33]. Thus, oxidation of the metallic $\mathrm{Pt} 0$ to $\mathrm{Pt}$ species with higher oxidation states occurred during the $\mathrm{O}_{3}+\mathrm{UV}_{254} \mathrm{~nm}$ photocatalytic process.

Following the $35-\mathrm{h} \mathrm{UV}_{254+185} \mathrm{~nm}$ photocatalytic process, the $\mathrm{Pt}^{-\mathrm{TiO}_{2}}$ displayed $\mathrm{Pt} 4 f_{7 / 2}$ peaks at 72.4 and $74.5 \mathrm{eV}$, which were assigned to $\mathrm{PtO}_{\text {ads }}(57.4 \%)$ and $\mathrm{Pt}^{4+}$ species (42.6\%), re-

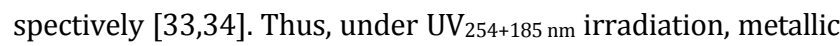
$\mathrm{Pt}^{0}$ was no longer apparent and more Pt species were oxidized to $\mathrm{Pt}^{4+}$. Because the light intensity of the $\mathrm{UV}_{254 \mathrm{~nm}}$ irradiation and concentration of $\mathrm{O}_{3}$ in the $\mathrm{O}_{3}+\mathrm{UV}_{254} \mathrm{~nm}$ photocatalytic system were comparable to those in the $\mathrm{UV}_{254+185 \mathrm{~nm}}$ photocatalytic system, the VUV-photochemically generated atomic oxygen species $\left(\mathrm{O}\left({ }^{1} \mathrm{D}\right), \mathrm{O}\left({ }^{3} \mathrm{P}\right)\right)$ and hydroxyl radicals $(\bullet \mathrm{OH})$ were likely to also contribute to the oxidation of the Pt species, thereby resulting in a large amount of $\mathrm{Pt}^{4+}$ species in the $\mathrm{UV}_{254+185} \mathrm{~nm}$ photocatalytic system.

\subsection{Effect of oxidized dispersed Pt species}

As discussed from the above comparative XPS study for the $\mathrm{Pt}_{-} \mathrm{TiO}_{2}$ films, the Pt species were significantly oxidized in the $\mathrm{O}_{3}+\mathrm{UV}_{254} \mathrm{~nm}$ photocatalytic system $\left(\mathrm{PtO}_{\text {ads }}(76.9 \%)\right.$ and $\mathrm{Pt}^{4+}$ species $(23.1 \%)$ ) whereas subtle changes were noted in the $\mathrm{UV}_{254} \mathrm{~nm}$ photocatalytic system. This clearly indicates that the added $\mathrm{O}_{3}$ should be involved in the oxidation of the Pt species. Falconer et al. [37] reported that Pt particles on $\mathrm{TiO}_{2}$ could serve as adsorption and reaction active sites for $\mathrm{O}_{3}$ decomposition. Thus, in the $\mathrm{O}_{3}+\mathrm{UV}_{254} \mathrm{~nm}$ photocatalytic system, Pt NPs can act as centers for capturing $\mathrm{O}_{3}$; the adsorbed $\mathrm{O}_{3}$ can then be readily reduced to ozonide radical anion $\left(\mathrm{O}_{3}{ }^{\circ-}\right)$ by reaction with the photogenerated electrons from $\mathrm{TiO}_{2}$ (Eq. (3)) [21,38,39]. The unstable $\mathrm{O}_{3}{ }^{*-}$ radicals rapidly split to form $\mathrm{O}_{2}$ and $0^{\bullet-}$ radicals under UV irradiation (Eq. (4)), as confirmed by ESR measurements $[40,41]$. The adsorbed water molecules on the Pt NPs can be oxidized by the $\mathrm{O}_{3^{\circ-}}$ and $\mathrm{O}^{\bullet-}$ radicals to form $\bullet \mathrm{OH}$ radicals (Eqs. (5) and (6)), resulting in abundant $\bullet \mathrm{OH}$ radicals on the surface of the Pt NPs. Owing to the strong oxidizing power of $\bullet \mathrm{OH}$ radicals, the $\bullet \mathrm{OH}$ radicals adsorbed on the Pt NPs are expected to oxidize metallic $\mathrm{Pt}^{0}$ to $\mathrm{Pt}$ species with higher oxidation states during the $\mathrm{O}_{3}+\mathrm{UV}_{254 \mathrm{~nm}}$ photocatalytic process (Eqs. (7) and (8)) [21].

$$
\begin{gathered}
\mathrm{O}_{3}+\mathrm{e}^{-} \rightarrow \mathrm{O}_{3}{ }^{--} \\
\mathrm{O}_{3^{--}+h v} \rightarrow \mathrm{O}_{2}+\mathrm{O}^{\cdot-}
\end{gathered}
$$




$$
\begin{gathered}
\mathrm{O}^{\bullet-}+\mathrm{H}_{2} \mathrm{O} \rightarrow \mathrm{OH}^{-}+\bullet \mathrm{OH} \\
\mathrm{O}_{3}{ }^{--}+\mathrm{H}_{2} \mathrm{O} \rightarrow \mathrm{OH}^{-}+\bullet \mathrm{OH}+\mathrm{O}_{2} \\
\mathrm{Pt}^{0}+2 \bullet \mathrm{OH} \rightarrow \mathrm{Pt}^{2+}\left(\mathrm{PtO}_{\text {ads }}\right)+2 \mathrm{OH}^{-} \\
\mathrm{Pt}^{2+}\left(\mathrm{PtO}_{\text {ads }}\right)+2 \cdot \mathrm{OH} \rightarrow \mathrm{Pt}^{4+}+2 \mathrm{OH}^{-}
\end{gathered}
$$

Pt species with high oxidation states have stronger electron affinities. Therefore, $\mathrm{PtO}_{\text {ads }}$ and $\mathrm{Pt}^{4+}$ species can act as electron trapping centers for the $\mathrm{Pt}_{-} \mathrm{TiO}_{2}$ nanocomposites in the $\mathrm{O}_{3}+\mathrm{UV}_{254} \mathrm{~nm}$ photocatalytic system. This will result in a more efficient photogenerated electron-hole pair separation, consequently resulting in a prolonged electron and hole lifetime. After trapping of the photogenerated electrons, the oxidized Pt species are reduced to $\mathrm{Pt}$ species with lower oxidation states (Eqs. (9) and (10)). The reduction of $\mathrm{PtO}_{2}$ to $\mathrm{Pt}^{0}$ in a reported photo-irradiated alcoholic suspension solution supports this assumption [42]. Thus, Pt species comprising both $\mathrm{PtO}_{\text {ads }}$ and $\mathrm{Pt}^{4+}$ species can steadily form on the $\mathrm{TiO}_{2}$ surface during the $\mathrm{O}_{3}+\mathrm{UV}_{254 \mathrm{~nm}}$ photocatalytic process.

$$
\begin{aligned}
& \mathrm{Pt}^{4+}+2 \mathrm{e}^{-} \rightarrow \mathrm{Pt}^{2+}\left(\mathrm{PtO}_{\text {ads }}\right) \\
& \mathrm{Pt}^{2+}\left(\mathrm{PtO}_{\text {ads }}\right)+2 \mathrm{e}^{-} \rightarrow \mathrm{Pt}^{0}
\end{aligned}
$$

In this work, the $\mathrm{O}_{3}$ concentration and light intensity of the $\mathrm{UV}_{254 \mathrm{~nm}}$ irradiation in the $\mathrm{UV}_{254+185 \mathrm{~nm}}$ photocatalytic system were comparable to those in the $\mathrm{O}_{3}+\mathrm{UV}_{254} \mathrm{~nm}$ photocatalytic system. Therefore, the reactions given in Eqs. (3)-(6) are also expected to occur, leading to a large amount of $\bullet \mathrm{OH}$ radicals on the Pt NPs in the $\mathrm{UV}_{254+185 \mathrm{~nm}}$ photocatalytic system. Additionally, the VUV-photochemically generated $\bullet \mathrm{OH}$ radicals must be present in gas phase and adsorb on active sites of the $\mathrm{Pt}-\mathrm{TiO}_{2}$ surface. Therefore, higher amounts of $\bullet \mathrm{OH}$ radicals are generated under $\mathrm{UV}_{254+185 \mathrm{~nm}}$ irradiation relative to $\mathrm{O}_{3}+\mathrm{UV}_{254 \mathrm{~nm}}$ irradiation, leading to enhanced oxidation of $\mathrm{Pt}$ species to $\mathrm{Pt}^{4+}$ species (Eq. (8)). The higher amount of $\mathrm{Pt}^{4+}$ species, as determined by Pt $4 f$ XPS, supports the above discussion relating to reaction

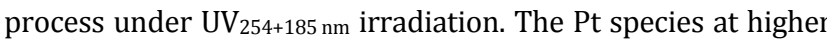
oxidation states can be also reduced according to Eqs. (9) and (10) to form mixed Pt species in the $\mathrm{UV}_{254+185 \mathrm{~nm}}$ photocatalytic system.

As mentioned above, the dispersed Pt species can effectively trap photogenerated electrons from the conduction band of $\mathrm{TiO}_{2}$, which helps to produce further $\bullet \mathrm{OH}$ radicals on $\mathrm{TiO}_{2}$ (Eqs. (11)-(13)). The surface unsaturated Pt atoms on the Pt NPs are highly active, and can act as reactive sites for adsorption and degradation of HCHO. Therefore, a larger number of $\bullet \mathrm{OH}$ radicals and reaction sites were observed on the $\mathrm{Pt}_{-} \mathrm{TiO}_{2}$ surface than on pure $\mathrm{TiO}_{2}$ in the $\mathrm{O}_{3}+\mathrm{UV}_{254} \mathrm{~nm}$ and $\mathrm{UV}_{254+185} \mathrm{~nm}$ photocatalytic systems, which resulted in a higher HCHO degradation rate, as observed in Fig. 3.

$$
\begin{gathered}
\mathrm{TiO}_{2}+h v \rightarrow h^{+}+\mathrm{e}^{-} \\
\mathrm{OH}^{-}(\mathrm{ads})+h^{+} \rightarrow \bullet \mathrm{OH}_{(\mathrm{ads})} \\
\mathrm{H}_{2} \mathrm{O}_{(\mathrm{ads})}+h^{+} \rightarrow \bullet \mathrm{OH}_{(\mathrm{ads})}+\mathrm{H}^{+}
\end{gathered}
$$

Compared with pure $\mathrm{TiO}_{2}$, oxidized Pt species, acting as effective redox catalysts, can provide more reactive sites for capturing $\mathrm{O}_{3}$ molecules [38], thus enhancing $\mathrm{O}_{3}$ decomposition. The adsorbed $\mathrm{O}_{3}$ molecules on the Pt NPs can be decomposed via the reactions given in Eqs. (3)-(6) by trapping the electrons generated upon UV irradiation. Additionally, thermal catalysis decomposition of $\mathrm{O}_{3}$ should be effective on oxidized $\mathrm{Pt}$ species [38]. Therefore, the higher $\mathrm{O}_{3}$ decomposition rate over the
Pt-TiO ${ }_{2}$ films relative to that over pure $\mathrm{TiO}_{2}$ under $\mathrm{O}_{3}+\mathrm{UV}_{254} \mathrm{~nm}$ and $U_{254+185} \mathrm{~nm}$ irradiation, as shown in Fig. 4, agrees with the reported study whereby Pt-loaded $\mathrm{TiO}_{2}$ accelerated the photocatalytic degradation of gaseous ozone [43].

\section{Conclusions}

XPS was used to assess the electronic states of $\mathrm{Pt}^{-\mathrm{TiO}_{2}}$ films employed for the photocatalytic degradation of formaldehyde under $\mathrm{UV}_{254 \mathrm{~nm}} \mathrm{O}_{3}+\mathrm{UV}_{254 \mathrm{~nm}}$, and $\mathrm{UV}_{254+185 \mathrm{~nm}}$ irradiation conditions. The formation of carbonyl and carboxyl groups, corresponding to formaldehyde and formic acid on the $\mathrm{Pt}-\mathrm{TiO}_{2}$ films following photocatalytic reactions, was determined by deconvolution of the $\mathrm{C} 1 s$ and $01 s$ XPS spectra. The content of the organic species on the $\mathrm{Pt}-\mathrm{TiO}_{2}$ and degree of catalyst deactivation under the studied conditions decreased in the order of $\mathrm{UV}_{254 \mathrm{~nm}}>\mathrm{O}_{3}+\mathrm{UV}_{254 \mathrm{~nm}}>\mathrm{UV}_{254+185 \mathrm{~nm}}$. More specifically, catalyst deactivation was negligible under $\mathrm{UV}_{254+185} \mathrm{~nm}$ irradiation. The accumulation of organic species on $\mathrm{Pt}-\mathrm{TiO}_{2}$, as determined by XPS, gives direct evidence to elucidate the degree of catalyst deactivation.

The deconvoluted Pt $4 f$ XPS spectra revealed that metallic $\mathrm{Pt}$ NPs were stable under $U_{254} \mathrm{~nm}$ irradiation; however, they were oxidized to a mixture of $\mathrm{PtO}_{\text {ads }}$ and $\mathrm{Pt}^{4+}$ species under $\mathrm{O}_{3}+\mathrm{UV}_{254}$ $\mathrm{nm}$ and $\mathrm{UV}_{254+185 \mathrm{~nm}}$ irradiation conditions. The $\bullet \mathrm{OH}$ radicals adsorbed on Pt NPs, generated during the $\mathrm{O}_{3}$ decomposition process or dissociation of water under 185-nm VUV, are expected to be involved in the oxidation of Pt species. Pt species with high oxidation states can readily trap the photogenerated electrons to increase the photocatalytic activity of $\mathrm{Pt}_{-} \mathrm{TiO}_{2}$. Ultrafine Pt NPs with a strong electron affinity can provide numerous reactive sites for $\mathrm{O}_{3}$ decomposition. Therefore, formaldehyde degradation and $\mathrm{O}_{3}$ elimination can be simultaneously enhanced in the $\mathrm{O}_{3}+\mathrm{UV}_{254 \mathrm{~nm}}$ and $\mathrm{UV}_{254+185 \mathrm{~nm}}$ irradiation photocatalytic systems by modifying $\mathrm{TiO}_{2}$ with $\mathrm{Pt}$.

\section{References}

[1] Hodgson A T, Destaillats H, Sullivan D P, Fisk W J. Indoor Air, 2007, 17: 305

[2] Pi Z, Cai L, Zhong J B, Gong M C, Chen Y Q. Chin J Catal (皮展, 蔡黎, 钟俊波, 龚茂初, 陈耀强. 催化学报), 2008, 29: 453

[3] Li J H, He H, Hu C, Zhao J C. Front Environ Sci Eng, 2013, 7: 302

[4] Jo W K, Kang H J. Chin J Catal (催化学报), 2012, 33: 1672

[5] Nie L H, Yu J G, Li X Y, Cheng B, Liu G, Jaroniec M. Environ Sci Technol, 2013, 47: 2777

[6] Yu J G, Li X Y, Xu Z H, Xiao W. Environ Sci Technol, 2013, 47: 9928

[7] Yu J G, Wang S H, Low J X, Xiao W. Phys Chem Chem Phys, 2013, 15: 16883

[8] Blount M C, Falconer J L. Appl Catal B, 2002, 39: 39

[9] Einaga H, Futamura S, Ibusuki T. Appl Catal B, 2002, 38: 215

[10] Obee T N, Hay S O. Environ Sci Technol, 1997, 31: 2034

[11] Ao C H, Lee S C, Mak C L, Chan L Y. Appl Catal B, 2003, 42: 119

[12] Kataoka S, Tompkins D T, Zeltner W A, Anderson M A.J Photochem Photobiol A, 2002, 148: 323

[13] Zhang P Y, Liang F Y, Yu G, Chen Q, Zhu W P.J Photochem Photobiol A, 2003, 156: 189

[14] Zhang P Y, Liu J.J Photochem Photobiol A, 2004, 167: 87

[15] Takeuchi M, Hidaka M, Anpo M. J Hazard Mater, 2012, 237-238: 


\title{
Graphical Abstract
}

Chin. J. Catal., 2014, 35: 210-218 doi: 10.1016/S1872-2067(12)60740-2

Characterization of $\mathrm{Pt}_{-\mathrm{TiO}_{2}}$ film used in three formaldehyde photocatalytic degradation systems: $\mathrm{UV}_{254} \mathrm{~nm}, \mathrm{O}_{3}+\mathrm{UV}_{254} \mathrm{~nm}$ and $\mathrm{UV}_{254+185} \mathrm{~nm}$ via $\mathrm{X}$-ray photoelectron spectroscopy

Pingfeng Fu, Pengyi Zhang*

University of Science and Technology Beijing; Tsinghua University
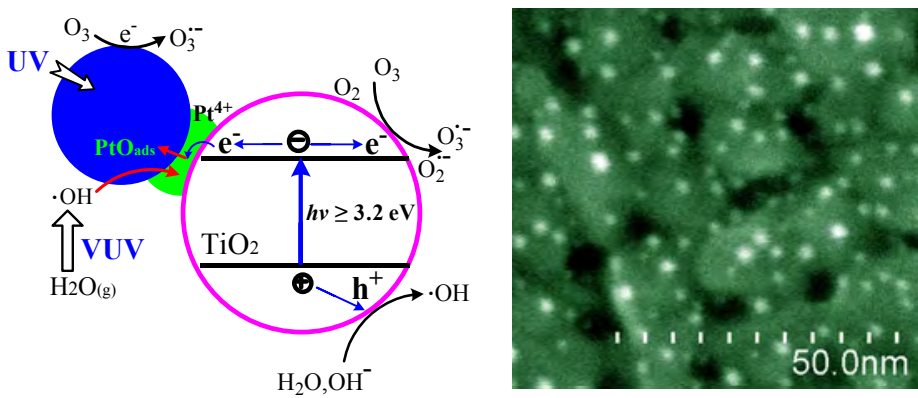

$\mathrm{O}_{3}$ byproduct can be photocatalytically decomposed on both $\mathrm{TiO}_{2}$ substrate and Pt nanoparticles under $\mathrm{UV}_{254+185} \mathrm{~nm}$ irradiation. The oxidized Pt species can trap the photogenerated electrons to increase the photocatalytic activity of $\mathrm{Pt}-\mathrm{TiO}_{2}$.

133

[16] Kibanova D, Sleiman M, Cervini-Silva J, Destaillats H. J Hazard Mater, 2002, 211-212: 233

[17] Zhang P Y, Liu J, Zhang Z L. Chem Lett, 2004, 33: 1242

[18] Jeong J, Sekiguchi K, Lee W, Sakamoto K. J Photochem Photobiol A, 2005, 169: 279

[19] Wang J H, Ray M B. Sep Purif Technol, 2000, 19: 11

[20] Jeong J, Sekiguchi K, Sakamoto K. Chemosphere, 2004, 57: 663

[21] Fu P F, Zhang P Y, Li J. Appl Catal B, 2011, 105: 220

[22] Quici N, Vera M L, Choi H, Puma G L, Dionysiou D D, Litter M I, Destaillats H. Appl Catal B, 2010, 95: 312

[23] Zhang L, Zhang P Y, Chen S Z. Chin J Catal (张丽, 张彭义, 陈崧哲. 催化学报), 2007, 28: 299

[24] Fu P F, Zhang P Y. Appl Catal B, 2010, 96: 176

[25] Fu P F, Luan Y, Dai X G. J Mol Catal A, 2004, 221: 81

[26] Kundu S, Wang Y M, Xia W, Muhler M. J Phys Chem C, 2008, 112: 16869

[27] Hoffmann M R, Martin S T, Choi W, Bahnemann D W. Chem Rev, 1995, 95: 69

[28] Okpalugo T I T, Papakonstantinou P, Murphy H, McLaughlin J, Brown N M D. Carbon, 2005, 43: 153

[29] Liu H M, Lian Z W, Ye X J, Shangguan W F. Chemosphere, 2005, 60: 630

[30] Shiraishi F, Ohkubo D, Toyoda K, Yamaguchi S. Chem Eng J, 2005,
114: 153

[31] Yu K P, Lee G W M. Appl Catal B, 2007, 75: 29

[32] Kibonova D, Cervini-Silva J, Destaillats H. Environ Sci Technol, 2009, 43: 1500

[33] Bera P, Priolkar K R, Gayen A, Sarode P R, Hegde M S, Emura S, Kumashiro R, Jayaram V, Subbanna G N. Chem Mater, 2003, 15: 2049

[34] Ohtani B, Iwai K, Nishimoto S-i, Sato S. J Phys Chem B, 1997, 101: 3349

[35] Dong F, Wang H Q Sen G, Wu Z B, Lee S C. J Hazard Mater, 2011, 187: 509

[36] Wu Z B, Sheng Z Y, Liu Y, Wang H Q Mo J S. J Hazard Mater, 2011, 185: 1053

[37] Falconer J L, Magrini-Bair K A. J Catal, 1998, 179: 171

[38] Lin J J, Kawai A, Nakajima T. Appl Catal B, 2002, 39: 157

[39] Naydenov A, Stoyanova R, Mehandjiev D. J Mol Catal A, 1995, 98: 9

[40] Hernández-Alonso M D, Coronado J M, Maira A J, Soria J, Loddo V, Augugliaro V. Appl Catal B, 2002, 39: 257

[41] Jiang C J, Zhang P Y, Zhang B, Li J G, Wang M X. Ozone Sci Eng, 2013, 35(4): 308

[42] Ohtani B, Kakimoto M, Nishimoto S, Kagiya T. J Photochem Photobiol A, 1993, 70: 265

[43] Cho K C, Hwang K C, Sano T, Takeuchi K, Matsuzawa S. J Photochem Photobiol A, 2004, 161: 155

\section{$X$ 射线光电子能谱法研究 $U V_{254} \mathrm{~nm}$ 光催化、 $O_{3}$ 强化 $U V_{254} \mathrm{~nm}$ 光催化和真空紫外光 催化降解甲醛中Pt-TiO 2 薄膜的表面性质}

\author{
傅平丰 ${ }^{\mathrm{a}}$, 张彭义 ${ }^{\mathrm{b}, *}$ \\ a 北京科技大学土木与环境工程学院, 北京 100083

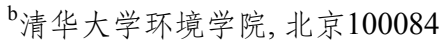

摘要: 以Pt- $\mathrm{TiO}_{2}$ 为光催化剂, 研究了气相甲醛分别在 35 h连续 $\mathrm{UV}_{254} \mathrm{~nm}$ 光催化、 $\mathrm{O}_{3}$ 强化 $\mathrm{UV}_{254} \mathrm{~nm}\left(\mathrm{O}_{3}+\mathrm{UV}_{254} \mathrm{~nm}\right)$ 光催化和真空紫外 $\left(\mathrm{UV}_{254+185 \mathrm{~nm}}\right)$ 光催化中的降解效率, 考察了副产物 $\mathrm{O}_{3}$ 的去除率, 采用X射线光电子能谱 $(X P S)$ 法分析 $\mathrm{Pt}-\mathrm{TiO}_{2}$ 在不同光催化前后Pt的 电子态和累积有机产物, 研究纳米 $\mathrm{Pt}$ 对甲醛降解和 $\mathrm{O}_{3}$ 去除的强化机理. 连续光催化降解实验表明, 以纳米 $\mathrm{Pt}$ 改性 $\mathrm{TiO}{ }_{2}$ 可以同时增 
强甲醛和 $\mathrm{O}_{3}$ 的去除率, 特别是 $\mathrm{O}_{3}$ 的去除率可提高3.1-3.4倍. 对催化剂 $\mathrm{C} 1 s$ 和 1 $1 s$ 峰分别经分峰拟合处理后, 发现 $\mathrm{Pt}^{-} \mathrm{TiO}_{2}$ 上累积的 含羰基和羟基的有机物含量按以下顺序减少: $\mathrm{UV}_{254 \mathrm{~nm}}$ 光催化 $>\mathrm{O}_{3}$ 强化UV $254 \mathrm{~nm}$ 光催化 $>$ 真空紫外光催化, 而在连续 $35 \mathrm{~h}$ 光催化 降解过程中, 催化剂的失活现象却按相反的方向变得越来越不明显. 负载的金属 $\mathrm{Pt}$ 在 $\mathrm{O}_{3}+\mathrm{UV}_{254} \mathrm{~mm}$ 和UV $254+185 \mathrm{~nm}$ 光催化过程中被氧 化成 $\mathrm{PtO}_{\mathrm{ads}}$ 和 $\mathrm{Pt}^{4+}$ 物种, 而在 $\mathrm{UV}_{254} \mathrm{~nm}$ 光催化过程中金属 $\mathrm{Pt}$ 未被氧化, 所以推测是气相中的 $\mathrm{O}_{3}$ 和羟基自由基参与金属 $\mathrm{Pt}$ 的氧化过程. $\mathrm{Pt}-\mathrm{TiO}_{2}$ 表面高价态的 $\mathrm{Pt}$ 氧化物种可作为光生电子捕获中心, 强化光生载流子的分离过程, 增强 $\mathrm{Pt}-\mathrm{TiO}_{2}$ 的光催化活性. $\mathrm{Pt}$ 氧化物种 可作为 $\mathrm{O}_{3}$ 分解的活化中心, 使 $\mathrm{Pt}-\mathrm{TiO}_{2}$ 对 $\mathrm{O}_{3}$ 的分解效率远高于纯 $\mathrm{TiO}_{2}$. 以XPS对比研究在三种不同光催化环境中 $\mathrm{Pt}^{-} \mathrm{TiO}_{2}$ 表面性质, 可以解释在 $\mathrm{UV}_{254+185 \mathrm{~nm}}$ 光催化过程中纳米 $\mathrm{Pt}$ 对甲醛和 $\mathrm{O}_{3}$ 同时去除的强化机理, 并说明了催化剂不失活的内在原因.

关键词: 纳米铂; 真空紫外光; 光催化; 臭氧分解; 催化剂失活

收稿日期: 2013-09-28. 接受日期: 2013-10-23. 出版日期: 2014-02-20.

*通讯联系人. 电话: (010)62796840-601; 传真: (010)627977602; 电子信箱：zpy@tsinghua.edu.cn

基金来源：国家自然科学基金(21221004); 国家高技术研究发展计划(863计划, 2012AA062701); 环境模拟与污染控制国家重点联 合实验室专项基金(12K04ESPCT).

本文的英文电子版由Elsevier出版社在ScienceDirect上出版(http://www.sciencedirect.com/science/journal/18722067). 